\title{
Managing Transboundary Crises: The Emergence of European Union Capacity
}

\section{Arjen Boin*, Mark Rhinard** and Magnus Ekengren***}

*Department of Political Science, Leiden University \& Public Administration Institute, Louisiana State University, PO Box 9555, 2300 RB Leiden, The Netherlands. E-mail: boin@Isu.edu

**Swedish Institute of International Affairs, Stockholm University, Box 27035, SE-10251 Stockholm, Sweden. E-mail: mark.rhinard@ui.se

***Swedish National Defence College, Box 27805, 11593 Stockholm, Sweden.

E-mail: magnus.ekengren@fhs.se

The European Union (EU) has modest but promising capacities to assist member states overwhelmed by disaster through its Civil Protection Mechanism. The EU also routinely sends civil and military missions to hotspots outside EU territory. But these capacities do not suffice in the face of transboundary crises: threats that cross geographical and policy borders within the Union. Examples include epidemics, financial crises, floods, and cyber terrorism. Nation states cannot cope with these threats without international collaboration. In this article, we explore the EU's efforts to develop transboundary crisis management capacities. We describe these budding capacities, explain their policy origins, and explore their future potential.

\section{Introduction: the prospect of transboundary crises}

O ver the years, the European Union (EU) has built a variety of capacities to coordinate the response of member states to natural disasters and foreign crises (Boin, Ekengren, \& Rhinard, 2013). Through its brandnew Emergency Response Centre, the Commission coordinates joint disaster assistance, both to member states and other disaster-stricken countries (Hollis, 2012; Morsut, 2014; Wendling, 2010). The EU routinely supports destabilized countries outside the EU through a variety of civil-military missions (Cottey, 2007; Jones, 2007; Kirchner \& Sperling, 2007; Norheim-Martinsen, 2013; Tercovich, 2014).

It is not clear, however, what the EU can do to facilitate a joint response to transboundary crises (Alemanno, 2011; Boin \& Rhinard, 2008; Jones, 2007). We speak of a transboundary crisis when the lifesustaining systems or critical infrastructures of multiple member states are acutely threatened (Ansell, Boin, \& Keller, 2010). We should, for example, think of breakdowns of the internet, electricity production, and gas supply or air control systems. Freak weather events, possibly as a result of climate change, can cause problems that affect entire regions. We can think of virulent forms of pandemic influenza or a large-scale attack with chemical or biological weapons.

The integration of Europe has made EU member states increasingly vulnerable to these transboundary crises (Missiroli, 2006; OECD, 2003, 2011; Sundelius, 2005). Many of the systems that sustain basic societal functions (e.g., energy grids, transport networks, food distribution, and financial flow structures) now reach across European political borders. As a result, an incident in one corner of Europe can turn into a crisis for the entire continent: the Chernobyl explosion, the outbreak of mad cow disease, a power outage in Germany, illegal immigration in Southern Europe, a blocked oil pipe in the Ukraine, an ash cloud above Iceland, or a 
budget problem in Greece - these are all instances of 'local' events that reached far beyond geographical and functional boundaries.

National governments cannot deal with these crises unilaterally, nor can they isolate themselves from these threats (Lagadec, 2009; Rhinard, 2009). The world especially Europe - has become too connected and too intertwined to avoid the reach of these crises. It has become nearly impossible to close borders and 'decouple' critical infrastructures.

In response to a transboundary crisis, an emergent network of local, national, and international actors must be cobbled together. This network has to be adaptable and scalable (Ansell et al., 2010). It has to cross boundaries between units, organizations, sectors, professions, and political jurisdictions; it must be able to validate information, facilitate and communicate decisions, and coordinate the implementation of these decisions.

The Solidarity Clause, enshrined as Article 222 in the Treaty on the Functioning of the European Union formulates explicit demands upon EU members to act jointly and to assist one another in the face of disasters, emergencies, and crises on the European continent. The question is whether, and to what extent, the EU has developed political-administrative capacities that facilitate a joint response to transboundary crises.

In this article, we search for those capacities and explore how they emerged. We analyse whether these capacities have become established or 'institutionalized' - meaning that they are used and found to be legitimate. The capacities we look for are scattered across the EU's various institutions, agencies, and policy fields. Our research, by necessity, has somewhat of a tour d'horizon character.

We begin our 'discovery process' by focusing on those policy sectors that have experienced a transboundary crisis, which leads us to suspect that these sectors may have developed transboundary crisis management capacities (even if these capacities are not labelled as such). In addition to 'vertical' (sector-specific) capacities, we look for 'horizontal' (sector-spanning) measures that can be used to manage transboundary threats, crises, and disasters. In the conclusion, we take stock and consider what our findings mean for future developments of EU crisis management capacity.

\section{Building transboundary crisis management capacity: a brief policy history}

Before the EU began building capacity to assist overwhelmed member states and before it began sending civil and military missions to hot spots around the world, the member states had already discovered the deep challenges posed by what we refer to as transboundary crises.
In the early morning of 26 April 1986, reactor 4 of the Chernobyl nuclear power plant in Ukraine suffered a massive nuclear chain reaction (Medvedev, 1992). The explosion released at least 100 times more radiation than the atomic bombs on Hiroshima and Nagasaki. Nearby regions in Belarus, Ukraine, and Russia received much of the fallout, but traces of radioactive deposits were found in nearly all countries in the northern hemisphere. People feared food might be contaminated and countries began to close their borders to produce from 'suspect' countries. The Commission was slow to respond and member states made little effort to coordinate (Liberatore, 1999).

In the early 1990 s, a rare but horrible neurological affliction, Creutzfeldt-Jakobs disease, became linked to a disease in cows [bovine spongiform encephalopathy (BSE) or mad cow disease]. On 20 March 1996, the British government acknowledged a possible connection between BSE and Creutzfeldt-Jakobs disease. Because there was an incubation period of several years, anybody who had ever eaten beef from the UK was potentially infected (Millstone \& Van Zwanenberg, 2001).

Almost immediately after the British announcement, several EU countries closed their borders to British beef. The mad cow scare, fuelled by frenzied media reporting, spiralled out of control and a full-fledged panic took hold of European consumers. The Commission's Scientific Veterinary Committee concluded that the UK had taken appropriate measures and no ban of UK beef would be necessary. But the Council's Standing Veterinary Committee, consisting of national representatives, voted 14 to 1 (the UK casting the dissenting vote) in favour of a ban on UK beef and related products (gelatine, tallow, and bull semen). The UK, under domestic pressure to retaliate against the imposed ban, announced a so-called 'non-cooperation policy' (Grönvall, 2001). The UK refused to cooperate with other member states in the European institutions, particularly by blocking measures in the Council. The EU's response to the BSE crisis has been widely described as a failure (Phillips, 2000; Vincent, 2004). ${ }^{1}$

These early encounters with transboundary crises exposed the EU's inability to produce a quick, coordinated, and joint response. They also demonstrated what the EU would need, at a minimum, to deal with this type of unfolding threat: a capacity to share information, to foster speedy and joint decision-making, and to speak with one voice.

Much of the subsequent efforts to build both threatspecific and generic capacities find their origin in the EU's policy area of Justice and Home Affairs (JHA; the Third Pillar until the Lisbon Treaty abolished the pillars) (Kaunert, 2010a). Confronted by the unintended consequences of their efforts to create open borders, member states were forced to contemplate 'flanking 
measures' to maintain safety and security in an increasingly borderless Europe. National and EU officials 'grind out an ever-growing range of legal and practical "flanking measures" needed to deepen cooperation between police, judges, border guards, customs officers, immigration officials, and other public authorities' (Brady, 2011).

This JHA area has seen a widening (but never formally agreed upon) definition of internal security. The initial initiatives were concerned with enhancing collaboration on criminal justice and border matters. After the $9 / 11$ events, counter-terrorism and the protection of critical infrastructures gained prominence. The idea of internal security eventually widened to include a wide variety of threats to the safety and well-being of citizens. Policy initiatives began to include the management of common threats and crises that reach across boundaries.

The Hague Programme (Council, 2004a), formulated in the post-9/11 world, identified the protection of critical infrastructures as a priority, along with 'consequence management' of terrorist attacks. It also gave rise to two generic crisis management capacities:Argus and the Crisis Coordination Arrangements (CCA). Argus is a web-based system that facilitates the sharing of crisis-related information across directorates in the Commission (Kjellen, 2009). Argus also serves as a 'network of networks' bringing together the many rapid-alert systems operating independently in various Commission directorates.

The CCA were designed to offer 'integrated and coordinated EU crisis management arrangements for crises with cross-border effects within the EU' (Council, 2004a, p. 24). The 9/11 attacks had contributed to a growing awareness that, outside of the normal legislative process, there was no procedure for national political representatives to join with the EU's institutional leadership to ensure a coordinated set of responses to such major events. This declaration, contained in Section 2.4 of the Hague Programme, is one of the few explicit acknowledgements in EU documents regarding the importance of preparing decision structures for transboundary crises. ${ }^{2}$ In theory, the CCA provided for a way to deal with the strategic and political dimensions of crisis decision-making. But they were never used and have been replaced by a new set of procedures (the Integrated Political Crisis Response, more in the succeeding paragraphs).

\subsection{Towards consolidation: the Stockholm Programme and the Internal Security Strategy}

The third multi-annual programme following the Tampere and Hague programmes, known as the Stockholm Programme, set out a range of initiatives for the period 2010-2014. The tone of the programme shifted from an emphasis on criminal justice and immigration to building a 'Europe that protects'. The 84-page document calls for a comprehensive, use all means available approach to protect EU citizens from a wide range of threats: "We need to address all the common security threats from terrorism and organized crime, to safety concerns related to man-made and natural disasters' (Commission, 2010, p. 5).

In March 2010, the Council adopted its Internal Security Strategy (ISS). In a follow-up document (The Internal Security Strategy in Action), five core threats were identified:

1. International crime networks

2. Terrorism and radicalization

3. Cyber threats

4. Border security

5. Crises and disasters

The Internal Security Strategy in Action also offers proposals to develop the EU regime for aviation and maritime security, common risk analyses, a coherent risk management policy, and a 'link up' of different situation awareness centres. For the period 2014-2020, the Commission (2010) is proposing an overall Home Affairs budget amounting to $€ 10.9$ billion, which represents an increase of almost $40 \%$ compared with the total budget for the period 2007-2013.

The implementation of ISS on the Commission side is in the hands of directorate-general (DG) Home, a newly organized DG still finding its footing. ${ }^{3}$ The Lisbon Treaty also created a Council committee, the Standing Committee on Internal Security (COSI), which should help to coordinate the implementation of ISS. COSI is a high-level working group: officials attend from capitals, meet for a day, and they decide on various courses of action that are proposed to the JHA Council. While conceived in some quarters to be the internal security equivalent of the Political and Security Committee, COSI has reportedly experienced a slow start and found it hard to develop a clear identity and a convincing modus operandi (House of Lords Select Committee on the European Union, 2011, pp. 51-52).

\subsection{After the Lisbon Treaty}

Since the Lisbon Treaty entered into effect, a wave of new policy initiatives has been set in motion. Implementation arrangements for the Lisbon Treaty's Solidarity Clause have been proposed, which may have far-reaching consequences for the ways in which the EU will assist member states overwhelmed by crises and disasters. The Civil Protection Mechanism has been moved to $\mathrm{DH} E C H O$ and is being reviewed as the Commission seeks to develop the European Disaster Response Capacity. The Commission's External Action Service is strengthening its capacity to coordinate crisis 
management abroad and provide consular protection of EU citizens (Tercovich, 2014).

But the most important development may well be the frantic development of 'sense-making tools', aimed at the collection, analysing, and sharing of information on the causes, dynamics, and effects of transboundary threats. The External Action Service's Situation Room operates 24/7 and is linked to the Intelligence Analysis Centre. The Consular Crisis Management unit manages the CoOL website that monitors real-time consular emergencies and services. DG ECHO's Emergency Response Centre aims to provide situational awareness during large-scale disasters. DG Home has created a Strategic Analysis and Response Centre, FRONTEX has its own analysis unit, the European Centre for Disease Prevention and Control (ECDC) permanently monitors communicable diseases, and the Joint Research Centre operates early warning systems for natural disasters. A recent inventory found 84 systems that could serve sense-making aims, one way or another (Boin, Ekengren, \& Rhinard, 2014).

In summary, we can say that the field of internal security is a work in progress. As transboundary crisis management initiatives typically impinge on national sovereignty - internal security is still a national responsibility enshrined in Article 72 of the Treaty on the Functioning of the European Union - efforts to enhance transboundary coordination and information-sharing have moved slowly.

In addition to DG Home, the EU has a plethora of organizations, policies, and instruments that may enhance a joint response to a transboundary threat. To get a better idea of this variety and the challenges it poses for any integrative effort, we will now take a brief look at the most prominent policy sectors in which transboundary crisis management capacities are being developed: counterterrorism, border management, communicable diseases, critical infrastructures, and finance.

\section{Countering terrorism}

European-wide cooperation on counter-terrorism commenced within the framework of the Trevi Group (Bures, 2011; Von Hippel, 2005). ${ }^{4}$ The Trevi Group (established in 1976) consisted of high-ranking officials from interior and home ministries, along with the heads of European security/intelligence agencies. Their informal gatherings facilitated the exchange of information and mutual assistance on terrorism and international crime. With the adoption of the Maastricht Treaty in 1992, the group was formally incorporated into the EU's third pillar.

At the Madrid European Council session of 1995, heads of state signalled their converging understanding that terrorism should be considered a common threat to democracy, economic, and social development. Further demonstrating the rise of terrorism on the EU's agenda, the Treaty of Amsterdam included a specific reference to the fight against terrorism, stating that 'preventing and combating crime, organized or otherwise, in particular terrorism' is one of the tasks of the Union in order to achieve the objective 'to provide citizens with a high level of safety within an area of freedom, security and justice' (Article 29, paragraph 2).

After the 11 September 2001 attacks, the European Council pledged to increase counter-terrorism cooperation (Argomaniz, 2011; Dalgaard-Nielsen \& Hamilton, 2006; Zimmermann, 2006). The EU adopted a 'Framework Decision on Combating Terrorism', which included a common definition of terrorism. The EU also adopted an 'Action Plan to Fight Terrorism' and a programme aimed at chemical, biological, radiological, and nuclear threats (Bossong, 2008).

In 2003, the Council adopted the European Security Strategy, which asserted that 'terrorism poses a growing strategic threat to the whole of Europe' and that 'Europe is both a target and a base for terrorism'. The Hague Programme (2004) emphasized prevention, preparedness, and response to terrorism offences, reduction of terrorists' financial and economic resources, and exchange of investigation information and protection of critical infrastructure programmes.

On 25 March 2004, two weeks after the Madrid bombings, the European Council called for a revised Plan of Action. The document recommended boosting the authority of Europol and authorized a specialist anti-terrorist unit to improve the sharing of police data and information and to conclude operational agreements with countries such as the United States. It also proposed further measures aimed at the suppression of terrorist financing, including several instruments to allow for the freezing of assets and the tracking of monetary transfers across borders.

The Plan of Action included plans for the implementation of the European Arrest Warrant, which was first introduced in the Council Framework Decision of 13 June 2002. The European Arrest Warrant requires EU member states to recognize and respond to surrender requests from fellow states. It is an instrument of 'mutual recognition', a principle by which member states must accept and recognize key measures in each other's judicial systems, and was envisioned to serve as the backbone for further JHA cooperation (Dittrich, 2005). That same year, the European Council created the new position of Counter Terrorism Coordinator. The London bombings of 7 July 2005 led to a number of additional initiatives (many already in the legislative pipeline)..$^{5}$

A substantial number of working groups and preparatory committees can be found in the area of counterterrorism cooperation (Dittrich, 2005). The Intelligence 
Analysis Centre assists the EU's External Action Service and the EU member states with analysis of international threats such as terrorism. The EU Police Chiefs' Task Force (established in 2000) provides a forum in which senior police authorities meet regularly to coordinate operational approaches to transnational crime problems. The COSI is the most recent addition to this already dense field.

The EU Health and Security Committee has established a 24 hour/7 days-a-week Rapid Alert System for Biological and Chemical Attacks and Threats (Sundelius \& Grönvall, 2004). This alert system relies heavily on the member states' surveillance systems for the occurrence of infectious diseases. It is operated by the ECDC.

The evolution of two agencies, Europol and Eurojust, reflects the institutionalization of EU transboundary crisis management capacities. Both agencies started their organizational lives as 'toothless tigers', but they have gradually developed into respected organizations in and through which specialists share information and initiate cooperation between relevant member state agencies (House of Lords Select Committee on the European Union, 2011; cf. Fijnaut, 2006; Kaunert, 2010b; Lavenex \& Wallace, 2005; Thwaites, 2006; Van den Wyngaert, 2006).

\section{Managing borders}

The Single European Act in 1986 turned the EU into 'an area without internal frontiers in which the free movement of goods, persons, services, and capital is ensured' (Single European Act, Article A). The prospect of open borders quickly drew attention to the problem of differentiated immigration and asylum procedures within Europe, and highlighted the need to not only improve coordination but also to formulate common policies (Balch \& Geddes, 2011; Barutciski, 1994; Monar, 2010).

The first Schengen Agreement (1985), which took a step towards abolishing border controls for individuals moving between signature countries, included only five of the then seven member states. The second Schengen Agreement (1990) took several steps further, establishing plans to completely abolish internal border controls, to create common external border policies, and to adopt common visa policies for third country individuals. Reacting to the problem of 'asylum shopping', Schengen countries signed the Dublin Convention (1990) by which the first country receiving an asylum application must examine and deal with the claim.

Developments on its southeastern border would quickly test the EU's remit. Yugoslavia slid into civil war in June 1991. By the end of 1993, more than 500,000 refugees had fled abroad (Carmichael, 2002). As migrants began pouring over the borders into Western Europe, some countries adopted special measures to accommodate them (Barutciski, 1994, p. 32). Other parts of Europe refused to lift normal asylum procedures or offer temporary protection. The effect was to drive migrants to European states which still offered refuge (Mazower, 2002). The EU was widely criticized for its understated role in the Balkans.

In 2002, at the Seville summit on combating illegal immigration, an action plan was adopted to guide the development of an integrated EU approach to border management. Still in effect today, it provides for a set of operational measures by member states aimed at improving coordination and cooperation, achieving a common integrated risk analysis, securing personnel and hardware for border management, and working towards common legislation on burden-sharing (llies, 2009, p. 6).

After the 'big bang' enlargement of the EU in 2004, the question of immigration, or more accurately, the shape of a common immigration policy, was considered with renewed urgency. At issue, and of concern to 'old' member states, was the movement of the EU's external border to new member states with 'untested' border protection capabilities. Internal security questions gained prominence, as the opening of internal borders was seen as a conduit for transnational crime, drug trafficking, and terrorism. This sense of urgency is clearly reflected in the Hague Programme (2004) and the Stockholm Programme's (2009) emphasis on managing borders.

A key part of the EU's border management approach is the creation of information databases and the use of new technologies (Dijstelbloem \& Meijer, 2011). For example, as a result of the creation of Schengen, police and judges now share information on individuals passing through the EU's external border. The Schengen Information System compiles this data. An expanded system (Schengen Information System II), which became operational in 2013, has the capability to store and exchange biometric data for use in security and law enforcement investigations (Brady, 2008, p. 24).

FRONTEX is one of the main structures through which EU member states cooperate on immigration issues (Leonard, 2010). Seated in Warsaw, Poland, FRONTEX took up its operational responsibilities in 2005. The regulation establishing FRONTEX sets out six tasks for the agency: (1) coordinate operational cooperation between member states in the field of management of external borders, (2) assist member states on training of national border guards, including the establishment of common training standards, (3) carry out risk analyses, (4) follow-up on the development of research relevant for the control and surveillance of external borders, (5) assist member states in circumstances requiring increased technical and operational assistance at external borders, and (6) provide member states with the necessary support in organizing joint return operations (Council, 2004b). 
While FRONTEX has received much attention, its actual remit is rather limited. Each EU member state remains responsible for managing its external borders, which means FRONTEX can only seek to further operational cooperation between member states. As it has few 'own resources', it also relies on the resources (e.g., officers, ships, helicopters) of member states. FRONTEX operates a satellite-based European External Border Surveillance System which is designed to provide full situational awareness and to enhance 'operational readiness' of law enforcement officials.

In 2007, EU interior ministers agreed to establish a rapidly deployable force of border guards to assist countries facing an immigration 'emergency'. RABIT teams, as these rapid border intervention teams are known, operate via FRONTEX and include a pool of over 450 national experts made available to any member state whose national borders are under 'urgent and exceptional' strain from unexpected migration (llies, 2009, p. 7). Record-high levels of immigration into the $\mathrm{EU}$ along the Greek-Turkish border in the second quarter of 2010 prompted the deployment of the first-ever RABIT team to help stem the flows and properly process asylum applications.

\section{Managing epidemics}

It was the Maastricht Treaty, signed in 1992, in which member states first agreed to some cooperation in the area of public health (Lezaun \& Groenleer, 2006). In 1998 , in the wake of the mad cow crisis, member states agreed to stronger cooperation in the form of a 'communicable diseases network' (Parliament and Council, 1998). That network, which is still in operation today (operated by ECDC) has been expanded to include all cross-border health threats and is used for surveillance, early detection of diseases, and early communication of response measures.

Further crises, including the Dioxin Scandal (1999) and SARS (2002) highlighted European vulnerabilities to health threats (MacLehose, McKee, \& Weinberg, 2002). After the emergence of $\mathrm{H} 5 \mathrm{~N} 1$ avian influenza in 2005, ministers agreed that 'EU member states need to coordinate efforts in the face of a risk of a human pandemic' and agreed to 'ensure strong coordination and information sharing' to minimize uncertainties during a pandemic outbreak (Press Release, 2005).

The EU is authorized to place certain communicable diseases on a watch list for monitoring and tracking (Commission, 2007). This list is updated when deemed necessary by the Commission, thus obligating member states to increase surveillance and reporting capacity regularly. The addition of new diseases to the watch list has led to 21 disease-specific networks that further bind national health authorities together. The 2009 $\mathrm{H} 1 \mathrm{~N} 1$ pandemic (also known as the 'swine flu') lead to a raft of new measures related to planning, situation monitoring and assessment, reducing the spread of the disease, providing adequate health care, and communicating with the public.

Public health policy at the EU level is formulated and managed through the Commission's DG for Public Health and Consumer Protection (DG Health, or known internally by its French acronym of 'DG Sanco'). Implementation and day-to-day policy management of health threats is the task of the 'health threats unit' founded in 2003 and located in Luxembourg. Here, we find a Crisis Room in which health-related rapid-alert systems are based (such as the Early Warning and Response System and the Rapid Alert System for Biological and Chemical Attacks and Threats).

In response to concerns that member states were not adequately prepared for communicable diseases, the ECDC was founded in 2004 in Stockholm, Sweden. The mission of the agency is to 'identify, assess, and communicate current and emerging threats to human health from communicable diseases' (Parliament and Council, 2004). The ECDC is, in other words, intended to consolidate the surveillance and early warning responsibilities that have been delegated to the European level. The ECDC functions as a repository of scientific knowledge that can be deployed across Europe, and as a source of 'best practice' for countries that may not have sufficient capacity.

\section{Managing critical infrastructures}

Global attention to so-called critical infrastructures can be traced to the $Y 2 \mathrm{~K}$ threat identified during the second half of the 1990s. Attention quickly dissipated after the feared paralysis of critical structures did not materialize in the first hours and days of the new millennium. After the events of $9 / 11$, critical infrastructure protection again moved to the top of national security agendas (Auerswald, Branscomb, LaPorte, \& Michel-Kerjan, 2006).

Many critical infrastructures reach across national borders. ${ }^{6} \mathrm{~A}$ role for the EU in guarding against breakdowns and preparing for failures therefore seems selfevident. Member states agree that the EU should have a role, but the precise nature of such a role remains unclear. Member states insist that critical infrastructure protection must remain a national competence, and that European-level programmes should show clear 'added value' and remain voluntary. Very few initiatives, beyond a large number of meetings, conferences, and feasibility studies have emerged on this issue as an initial spate of ideas and proposals. ${ }^{7}$

In April 2007, cyber attacks swamped websites of Estonian government agencies, communication services, media outlets, and major banks. The attacks forced Estonia to shut down all incoming foreign internet 
traffic. The scale of the attack, the organization of the attackers, and the threat it posed to Estonian national security took this event beyond a minor hacking incident to a full-fledged internet sabotage with implications for regional security and stability. Cyber security subsequently assumed a prominent position in both the Stockholm Programme and the EU's ISS.

We can find additional and often more concrete initiatives aimed at protecting critical infrastructures by looking into specific policy areas (Fritzon, Ljungkvist, Boin, \& Rhinard, 2007). Within the food sector, for instance, European-level attention is being placed on protecting the food supply chain 'from farm to fork' through standard setting, inspection control, and harmonization (Commission, 2008). Legislative proposals have been formulated to make supplies more secure through the maintenance of minimum stocks of crude oil and petroleum products, putting in place emergency procedures to be used in the event of a shortage (Council, 2009). Road, sea, and air transport policies in the EU have been supplemented with a variety of security measures intended to prevent breakdowns in critical transport networks. In the aftermath of the Icelandic ash cloud crisis (2010), the EU moved to improve airtraffic coordination.

The EU's critical infrastructure protection policy is managed by officials from the Commission's DG for Home Affairs. One structure to emerge in this area is CIWIN, a critical infrastructure warning information network. Within specific sectors, additional structures can be found. For the protection of critical information infrastructures, for instance, the EU's agency for network and information security (ENISA) offers a hub for coordination. Created in 2004, ENISA has a broad but fairly shallow mandate, charged with assisting member states, public organizations, and industries to prevent, manage, and solve problems of ICT security. ENISA, however, has no decision-making authority on policy questions. The Commission's Internal Security Strategy in Action announced the initiation of the EU Cybercrime Centre, which became operational in 2013 and is placed within Europol. The EU has launched a project focused on building, and ensuring the resilience of, trans-European energy networks (the TEN-E project). In 2002, the European aviation safety agency was established with wide-ranging regulatory and executive tasks.

\section{Managing financial crises}

The global financial crisis brutally exposed the lack of financial crisis management capacities at the European level. European leaders consistently failed to 'get ahead' of the financial crisis, which, in turn, fed a legitimacy crisis for the Euro and the very idea of European unity.
The global financial crisis demonstrated, more specifically, two shortcomings of the EU's financial infrastructure (Quaglia, 2013). First, it exposed the absence of financial supervision at the European level. Although the EU's role in financial regulation grew during this period, its role in financial supervision did not. Second, it showed that a lack of crisis management instruments translates into slow and incremental decision-making. National governments have been slow to give up substantial supervisory responsibilities to the European level, and there is only limited legal authority in the EU treaties on the subject of supervision.

The key actors involved in financial regulation and supervision in the EU include the European Commission (DG Internal Market), the Council of the European Union (more specifically, the Economic and Finance Council), and the European Central Bank (ECB).

The ECB gained prominence during the crisis. Headquartered in Frankfurt, the ECB serves as the central bank of the Eurozone. Like any central bank, its primary objective is to maintain price stability. Its key tasks are to define and implement the Eurozone's monetary policy, to conduct foreign exchange operations, to manage the foreign reserves of the European System of Central Banks, to promote a sound financial market infrastructure in Europe, and to authorize the issuance of Euro bank notes (Leino, 2000). The ECB's role as a lender of last resort is highly constrained (Schinasi \& Teixeira, 2006). It cannot recapitalize banks or apply massive economic stimulus measures.

Four additional institutions emerged in 2011. The European Systemic Risk Board, chaired by the ECB president, will have powers to issue warnings and recommendations when it sees threats to economies or financial systems. This will help the ECB's capacity of surveillance. In addition, the EU created the European Banking Authority, the European Insurance and Occupational Pensions Authority, and the European Securities and Markets Authority.

The EU has reacted with a spate of policy and institutional innovations (Antoniadis, 2011). In these reform efforts, improvisation reigned supreme. As the Financial Times commentator Martin Wolf put it: 'the Eurozone's aeroplane is being redesigned while crashing' ${ }^{8}$ Yet, many of the Commission's proposals towards greater coordination have been met with reluctance or outright hostility. Decision processes for ensuring financial stability and crisis management remain firmly anchored at the national level.

\section{Analysis: a fragmented field inching towards institutionalization?}

The EU's transboundary crisis management tools are scattered across the EU's institutions. Some policies and organizational units have become fairly well established 
and appear to be ascending, however slowly, the institutionalization ladder (think of Argus, FRONTEX and Europol). Other initiatives, such as the ISS, are young but promising. Yet others were slow to take off and struggled to develop a recognizable identity (CCA and COSI). There is no observable logic tying these capacities together (cf. Kaunert, Leonard, \& Pawlak, 2012). There is no centralized department for transboundary crisis management; it is a field without a name (in organizational diagrams and in textbooks, this field does not feature). It is not even clear who in the EU is aware of all these available capacities. ${ }^{9}$

Why does the field of transboundary crisis management not rank much higher in terms of institutionalization? The very idea of transboundary crisis management fits the core principles of subsidiarity and 'adding value' (the idea that the EU should only initiate activities that member states cannot or will not do alone). Moreover, the EU has faced several transboundary crises that demonstrated why a joint response is both necessary and helpful. So why has this field not developed like the Civil Protection area or the Common Security and Defence Policy arena - policy fields that arguably had less 'institutionalization potential'? We argue that the answer can be found in a combination of ambiguous ambitions, the EU's capacity to adapt, and the underlying legitimacy of EU transboundary crisis management (Boin et al., 2013).

\subsection{Ambiguous ambitions}

The continuing drive to create an open market across the European continent reliably produces opportunities for small problems to propel themselves across borders and snowball into a new, hard-to-manage type of adversity. Whether we speak of the Iceland Ash Crisis or the mysterious EHEC outbreak, the financial crisis, or the unfolding consequences of climate change, it is widely realized that Europe faces the prospect of transboundary crises. It is therefore no surprise to hear Cecilia Malmström (2010), Commissioner for Home Affairs, argue that the EU should 'better protect the life and safety of EU citizens against all threats and hazards'. ${ }^{10}$

It is hard to find a clarion call for the creation of transboundary crisis management capacity at the EU level. Lofty rhetoric about a 'secure Europe' suggests an important role for the EU. But references to the actual construction or enhancement of transboundary crisis management capacity tend to be vague, underdeveloped, or unfeasible. There is not even a definition of what would constitute a crisis for the EU.

One of the reasons for this understated response to a recognized problem are differences in opinion among national governments over what the EU's role in transboundary crisis management should be. This is not just a problem of conflicting national interests. It also reflects a lack of understanding about the essential characteristics of transboundary crises and the required response capacities at the European level. How do we prevent a smallpox outbreak or a cyber attack? What response capacities are needed when acute energy shortages occur in deep winter? In the absence of such knowledge, political leaders are prone to cast the EU's role in ambiguous and modest terms: the EU should do more, but member states should retain a final say. This explains why the EU's formal competences rarely correspond with the kinds of activities demanded by managing transboundary crises.

Another reason is the linkage between security and crisis: the few concerted efforts to create transboundary crisis management capacities are mostly wrapped up in wider initiatives related to internal security. By formulating crisis management initiatives in terms of security, these initiatives fall within the domain of interior and justice ministers - not the most reformminded group of policy actors (Brady, 2011). Moreover, since the Lisbon Treaty has brought the Parliament and European Court of Justice into the highly sensitive areas of criminal justice and police cooperation, an atmosphere of reluctance and scepticism has descended upon the internal security policy arena (Bossong \& Rhinard, 2013).

The absence of a clearly recognized 'problem owner' does not help. The organization of the Commission into policy-specific directorates has long been the source of policy fragmentation and coordination problems (Christiansen, 2006). For many years, this meant that the Commission's various crisis management initiatives took place with little mutual awareness and even less overarching guidance. While DG Home has taken the lead in attempting to formulate a more comprehensive view on transboundary crisis management, it holds little or no authority over some of the relevant tools and policies. DG Home has declared its interest to 'decide how we can implement the Solidarity Clause in a much better way', for instance, but the Civil Protection Mechanism (a tool that is pertinent to the Solidarity Clause) falls within the remit of DG ECHO (Malmström, 2010; cf. House of Lords Select Committee on the European Union, 2011, p. 3).

Under these conditions, it is no surprise that institutionalization in this area has been slow and uneven. It takes time, experimentation, and adaptation to translate ambitious and ambiguous policy aims into relevant, effective, and legitimate practices. Once initiatives get off the ground, they can grow by demonstrating their added value.

The question is whether this policy arena will have enough time to allow such institutionalization processes to occur. Crises and disasters are not likely to 
abate nor are they likely to become more 'localized' and less transboundary. Future crises will trigger repeated interventions by political leadership, which will result in additional and ever more ambitious policy aims. Institutionalization, in other words, will demand adaptive capacity on the part of EU institutions.

\subsection{The capacity to adapt}

At the same time, and somewhat curiously, the EU policy process inexorably muddles on and continues to produce new transboundary crisis management capacities. The EU manages to translate highly ambiguous and seemingly impossible ambitions into practices that prove to be useful. This explains the slow yet continuous expansion of the EU's transboundary crisis management capacities.

We can observe a pattern here. Most new policy initiatives on transboundary crisis management are reactions to systemic 'shocks' (cf. Argomaniz, 2009; Sabatier \& Jenkins-Smith, 1993). When a crisis confronts member states with their shortcomings, the EU is quick to suggest a role for itself. In response to the mad cow disease, for instance, member states agreed to new health security measures and the Commission built institutions for regulating animal and human health questions. More recently, terror attacks have had a galvanizing effect on collective action in crisis management (Argomaniz, 2009). These events suggested the need for a Europe-wide response, generating a host of new measures regarding internal security, such as biosafety preparedness, customs controls, joint policing, and intelligence sharing.

Something has to happen 'on the ground' if these policy initiatives are to produce results. Perhaps, the most typical example of how this tends to happen in this policy area is found in the institutional history of Europol. Initially, distrusted widely and starting its life with clipped wings, Europol managed to grow step by step. Rob Wainwright, director of Europol, explains how this process works:

From the start, we have had to fight for our natural space in the hearts and minds of the police. We have to do that through hard labour, demonstrating to investigators in our 12,000 to 13,000 cases the unique value that we can add. [...] One of the cornerstones of our ambition is to become what I would describe as the information hub for police work in the EU (House of Lords Select Committee on the European Union, 2011, p. 48).

The financial crisis tested the EU's capacity to adapt 'in real time'. While the EU has been consistently criticized for not 'getting ahead' of this crisis, it also demonstrated a remarkable potential to revise policies and initiate new tools 'on the fly' - offering reform that was considered unthinkable only months earlier.

This is, of course, not true for each initiative launched in this policy area. One of the most promising tools the CCA - was never used and has been replaced. Other organizations, such as Eurojust and ENISA, struggle to gain widespread recognition. The EU Counterterrorism Coordinator appears to be in an 'existential crisis' (as the ISS and COSI have made the position more or less redundant). The COSI was off to a slow start and has shown few signs of establishing itself.

\subsection{Surprising legitimacy: a potential source of forward momentum}

Even though the formulation of ambitions and the coherence of EU action in this area reveal a considerable amount of uncertainty and fragmentation, we see growing legitimacy for the EU's transboundary crisis management capacities. When asked, Europe's citizens overwhelmingly agree that the EU should work to make Europe safer. Opinion polls confirm that the public sees cooperation on terrorism, health threats, cyber crime, and border security as a key role for the EU (Commission, 2006, 2011).

The European Parliament, while occasionally sceptical of security-related initiatives, generally approves of the EU's broader role of acting to safeguard the well-being of European citizens. This is apparent in political declarations, in which the European Parliament claims credit for assisting in such efforts (Parliament, 2012) as well in evaluations of the EU's role in handling crises (Parliament, 2011).

Member states routinely agree to upgrade capacities after crises. Indeed, rarely does a meeting of government officials (in the EU's Council of Ministers, for instance) pass without reference to the need for stronger cooperation to overcome the limitations of national action. This does not mean that member states are ardent cheerleaders for an expanding EU role. Most governments remain hesitant at best to use some of the EU's capacities. To some extent this is a matter of national pride, in that some countries do not want to appear 'weak' and in need of assistance. This may also be a matter of sovereignty because some countries may not want to share what they feel to be sensitive information. While this hesitation is understandable and unlikely to dissipate any time soon, it explains why we cannot expect rapid or deep institutionalization of transboundary crisis management capacities at the European level - even if it were a rational and desirable course of action in the light of future crises.

\section{Conclusion: towards integration?}

One might argue that the EU was born out of the biggest transboundary crisis ever witnessed on the 
European continent. On the ruins of war-ravaged Europe, six nations came together to create a unique form of cooperation to make sure a similar disaster would never occur again. The founders of the European Community built strong economic ties to help member states rebuild and prosper, while preventing future manifestations of the distinctly transboundary threat of war.

In its 50 plus years, the EU did not see any wars within its boundaries. But it did confront several transboundary threats, which posed complex challenges to member states and the EU. In response, the EU has developed transboundary crisis management capacities: instruments, policies, and venues that can be used in response to transboundary threats and crises. But these capacities have not, or hardly, been institutionalized.

The emergence of new transboundary threats and crises will set the stage for further institutionalization. This can happen quite quickly, as demonstrated in the financial realm. It can move slowly, as seems to be happening in the area of critical infrastructure protection. As it stands, the EU is still far removed from acting in an autonomous fashion in response to transboundary crises. Member states maintain full authority and choose which tasks they want to delegate to the EU. Many member states are also slow to implement commitments made in EU venues.

Moreover, The EU is still wrestling to provide an encompassing mission for these capacities and an administrative apparatus to coordinate the various organizational and policy tools (cf. Boin \& Ekengren, 2009). EU policymakers routinely call for a streamlining of capacities, but the tensions between EU institutions and the reluctance of member states to grant more powers to Brussels make this an unlikely prospect. Future crises will likely provide the impetus to move towards a more integrated approach.

\section{Notes}

1. Following the BSE crisis, the Commission took some major steps towards dealing more effectively with this type of transboundary crisis (Ansell \& Vogel, 2006). In 2002, the European Food Safety Agency was created for risk assessment and risk communication on food safety questions. The agency operates the Rapid Alert System for Food and Feed, which comprises a network of monitors in every member state and flags dangerous trends in the food supply.

2. The examples used to justify this new arrangement were the possibility of needing to shut down airports, respond to a string of terror attacks, or manage the knock-on effects of a pandemic (Gustenau, 2006).

3. DG Justice, Freedom, and Security was split in 2010, following a Commission reorganization, into two separate directors-general: DG Home, responsible for internal police, immigration, and security questions, and DG
Justice and Fundamental Rights, responsible for judicial cooperation.

4. TREVI stands for Terrorism, Radicalisation, Extremism and International Violence.

5. For an overview of EU anti-terror measures, see Cottey (2007, pp. 178-179).

6. Critical infrastructures are defined as 'those physical and information technology facilities, networks, services, and assets which if disrupted or destroyed, would have a serious impact on the health, safety, security, or economic well-being of citizens or the effective functioning of governments in the member states' (Commission, 2004, p. 3).

7. In 2005, the Commission published a 'Green Paper' laying out ideas for a 'European Programme for Critical Infrastructure Protection' (Commission, 2005).

8. Martin Wolf (2012) The Union outlived de Tocqueville. Financial Times, 18 April, p. 11.

9. In 2009, the Secretariat General of the Commission made a first attempt to create an overview of available capacities. The result, titled 'Inventory of Crisis Management Capacities in the European Commission and Community Agencies', was published as an internal Commission document. In 2011, a 'corrigendum' was published.

10. Speech at the Conference on Research Development and Innovation for a more Secure Europe. Oostende, 23 November 2010. This ambition is, of course, overstated. The ISS aims to define 'a few limited but common threats'.

\section{References}

Alemanno, A. (2011), Governing Disasters: The Challenges of Emergency Risk Regulation, Edward Elgar Publishing, Cheltenham.

Ansell, C. and Vogel, D. (eds) (2006), What's the Beef: The Contested Governance of European Food Safety, The MIT Press, Cambridge.

Ansell, C., Boin, R. A. and Keller, A. (2010), 'Managing Transboundary Crises: Identifying the Building Blocks of an Effective Response System', Journal of Contingencies and Crisis Management, Volume 18, Number 4, pp. 195207.

Antoniadis, A. (2011), 'Debt Crisis as a Global Emergency: The European Economic Constitution and Other Greek Fables', in Antoniadis, A., Schutze, R. and Spaventa, E. (eds), The European Union and Global Emergencies: A Law and Policy Analysis, Hart Publishing, Oxford, pp. 167-191.

Argomaniz, J. (2009), 'Post-9/11 Institutionalisation of European Union Counterterrorism: Emergence,Acceleration and Inertia', European Security, Volume 18, Number 2, pp. 151-172.

Argomaniz, J. (2011), The EU and Counter-Terrorism, Routledge, London.

Auerswald, P. E., Branscomb, L. M., LaPorte, T. M. and Michel-Kerjan, E. O. (eds) (2006), Seeds of Disaster, Roots of Response: How Private Action Can Reduce Public Vulnerability, Cambridge University Press, New York.

Balch, A. and Geddes, A. (2011), 'Opportunity from Crisis? Organisational Responses to Human Trafficking in the UK', The British Journal of Politics \& International Relations, Volume 13, Number 1, pp. 26-41.

Barutciski, M. (1994), 'EU States and the Refugee Crisis in the Former Yugoslavia', Refuge, Volume 14, Number 3, pp. 32-35.

Boin, A. and Ekengren, M. (2009), 'Preparing for the World Risk Society: Towards a New Security Paradigm for the European Union', Journal of Contingencies and Crisis Management, Volume 17, Number 4, pp. 285-294.

Boin, A. and Rhinard, M. (2008), 'Managing Transboundary Crises: What Role for the European Union?', International Studies Review, Volume 10, Number 1, pP. $1-26$.

Boin, A., Ekengren, M. and Rhinard, M. (2013), The EU as Crisis Manager: Patterns and Prospects, Cambridge University Press, Cambridge.

Boin, A., Ekengren, M. and Rhinard, M. (2014), Sense-Making in Crises: What Role for the EU?, National Defence College, Stockholm. 
Bossong, R. (2008), 'The Action Plan on Combating Terrorism: A Flawed Instrument of EU Security Governance', Journal of Common Market Studies, Volume 46, Number 1, pp. 27-48.

Bossong, R. and Rhinard, M. (2013), 'European Internal Security as a Public Good', European Security, Volume 22, Number 2, pp. 129-147.

Brady, H. (2008), EU Immigration Policy, Centre for European Reform Briefing, London.

Brady, H. (2011), Inquiry into the EU Internal Security Strategy (Oral and Associated Written Evidence), House of Lords, London.

Bures, O. (2011), EU Counterterrorism Policy: A Paper Tiger?, Ashgate, Farnham.

Carmichael, C. (2002), Ethnic Cleansing in the Balkans: Nationalism and the Destruction of Tradition, Routledge, London.

Christiansen, T. (2006), 'The European Commission: The European Executive between Continuity and Change', in Richardson, J. (ed.), European Union: Power and Policy-Making, Routledge, Abingdon, UK, pp. 99-120.

Commission (2004), 'Critical Infrastructure Protection in the fight against terrorism', Communication from the Commission to the Council and the European Parliament, Reference No. COM/2004/0702 final.

Commission (2005), Green Paper on a European Programme for Critical Infrastructure Protection, Brussels, 17 November 2005, Reference No. $\operatorname{COM}(2005) 576$ final.

Commission (2006), Special Eurobarometer 257 'Avian Influenza', June 2006.

Commission (2007), Decision amending Decision No 2119/98/EC of the European Parliament and of the Council and Decision 2000/96/EC as regards communicable diseases listed in those decisions, Brussels: 18 December 2007, Reference No. 2007/875/ EC.

Commission (2008), Food: From Farm to Fork Statistics, Office for Official Publications of the European Communities, Luxembourg.

Commission (2010), 'Communication on the EU Internal Security Strategy in Action: Five Steps Towards a More Secure Europe', Brussels: 22 November 2010, Reference No. COM (2010) 673 final.

Commission (2011), Special Eurobarometer 371 'Internal Security', November 2011.

Cottey, A. (2007), Security in the New Europe, Palgrave, New York.

Council (2004a), 'The Hague Programme: strengthening freedom, security and justice in the European Union', Brussels: 13 December 2004, Reference No. $16054 / 04$.

Council (2004b), 'Council Regulation (EC) No. 2007/2004 of 26 October 2004 establishing a European Agency for the Management of Operational Cooperation at the External Borders of the Member States of the European Union'.

Council (2009), 'Council Directive 2009/119/EC of 14 September 2009 imposing an obligation on Member States to maintain minimum stocks of crude oil and/or petroleum products', Reference No. L 265/9.

Dalgaard-Nielsen, A. and Hamilton, D. S. (eds) (2006), Transatlantic Homeland Security: Protecting Society in the Age of Catastrophic Terrorism, Routledge, London.

Dijstelbloem, H. and Meijer, A. (eds) (2011), Migration and the New Technological Borders of Europe, Palgrave Macmillan, London.

Dittrich, M. (2005), Facing the Global Terrorist Threat: A European Response, Working Paper No. 14, January 2005, European Policy Centre, Brussels.

Fijnaut, C. (2006), 'Police Cooperation and the Area of Freedom, Security and Justice', in Walker, N. (ed.), Europe's Area of Freedom, Security, and Justice, Oxford University Press, Oxford, pp. 253-258.

Fritzon, A., Ljungkvist, K., Boin, R.A. and Rhinard, M. (2007), 'Protecting Europe's Critical Infrastructures: Problems and Prospects', Journal of Contingencies and Crisis Management, Volume 15, Number 1, pp. 30-41.

Grönvall,J. (2001),'Mad Cow Disease: The Role of Experts and European Crisis Management', in Rosenthal, U., Boin, R.A. and Comfort, L. K. (eds), Managing Crises: Threats, Dilemmas, Opportunities, Charles C. Thomas, Springfield, IL, PP. 155-174.

Gustenau, G. (2006), 'The Concept of Homeland Security in the European Union and in Austria: A Challenge for the Austrian EU presidency', in Esther, B. (ed.), Transforming Homeland Security: U.S. and European Approaches, Center for Transatlantic Relations, Washington, pp. 59-80.

Hollis, S. (2012), 'A rational response to natural disasters?: Explaining the global rise of regional disaster risk management', PhD dissertation, Hertie School of Governance, Berlin.

House of Lords Select Committee on the European Union (2011), Inquiry into the EU Internal Security Strategy, House of Lords, London.

Ilies, M. (2009), 'Irregular Immigration Policy in the European Union: Action at all Stages of the Irregular Migration Flow', Real Instituto Elcano, Working Paper 38/2009.
Jones, S. (2007), The Rise of European Security Cooperation, Cambridge University Press, Cambridge.

Kaunert, C. (2010a), European Internal Security: Towards Supranational Governance in the Area of Freedom, Security and Justice?, Manchester University Press, Manchester.

Kaunert, C. (2010b), 'Europol and EU Counter-Terrorism: International Security Actorness in the External Dimension?', Studies in Conflict and Terrorism, Volume 33, Number 7, pp. 652-671.

Kaunert, C., Leonard, S. and Pawlak, P. (eds) (2012), European Homeland Security: A Strategy in the Making?, Routledge, London.

Kirchner, E. J. and Sperling, J. (eds) (2007), Global Security Governance: Competing Conceptions of Security in the $21^{\text {st }}$ Century, Routledge, Abingdon.

Kjellen, S. (2009), 'Rapid Alerts for Crises at the EU Level', in Olsson, S. (ed.), Crisis Management in the European Union: Cooperation in the Face of Emergencies, Springer, Berlin, pp. 61-82.

Lagadec, P. (2009), 'A New Cosmology of Risks and Crises: Time for a Radical Shift in Paradigm and Practice', Review of Policy Research, Volume 26, Number 4, pp. 473-486.

Lavenex, S. and Wallace, W. (2005), 'Justice and Home Affairs: Towards a "European Public Order" ', in Wallace, H., Wallace, W. and Pollack, M.A. (eds), Policy-Making in the European Union, Oxford University Press, Oxford, PP. $457-480$.

Leino, P. (2000), 'The European Central Bank and legitimacy: Is the ECB a modification of or an exception to the principle of democracy?', Harvard Jean Monnet Working Paper 1/01, Harvard Law School, Cambridge.

Leonard, S. (2010), 'EU Border Security and Migration into the European Union: Frontex and Securitization through Practices', European Security, Volume 19, Number 2, pp. 231-254.

Lezaun, J. and Groenleer, M. (2006), 'Food Control Emergencies and the Territorialisation of the European Union', Journal of European Integration, Volume 28, Number 5, pp. 437-455.

Liberatore, A. (1999), The Management of Uncertainty: Learning from Chernobyl, Gordon and Breach Publishers, Amsterdam.

MacLehose, L., McKee, M. and Weinberg, J. (2002), 'Responding to the Challenge of Communicable Disease in Europe', Science, Volume 295, Number 5562, pp. 2047-2050.

Malmström, C. (2010), 'Speech at the Belgian Presidency conference on Research development and innovation for a more secure Europe', 23 November 2010, Oostende.

Mazower, M. (2002), The Balkans: A Short History, Modern Library Press, London. Medvedev, Z. A. (1992), The Legacy of Chernobyl, W.W. Norton, London.

Millstone, E. and Van Zwanenberg, P. (2001), 'Politics of Expert Advice: Lessons from the Early History of the BSE Saga', Science and Public Policy, Volume 28, Number 2, pp. 99-112.

Missiroli, A. (2006), 'Disasters Past and Present: Challenges for the EU', Journal of European Integration, Volume 28, Number 5, pp. 423-436.

Monar, J. (2010), 'Justice and Home Affairs', Journal of Common Market Studies, Volume 48, Number S1, pp. 143-162.

Morsut, C. (2014), 'The EU's Community Mechanism for Civil Protection: Analysing its Development', Journal of Contingencies and Crisis Management, Volume 22, Number 3, pp. 143-149.

Norheim-Martinsen, P. M. (2013), The European Union and Military Force, Cambridge University Press, Cambridge.

OECD (2003), Emerging Risks in the 21st Century: An Agenda for Action, OECD, Paris.

OECD (2011), Future Global Shocks: Improving Risk Governance, OECD, Paris.

Parliament (2011), 'Report on the EU Counter-Terrorism Policy: Main achievements and future challenges', Committee on Civil Liberties, Justice, and Home Affairs, 20 July 2011., Reference No. A7-0286/2011.

Parliament (2012), 'Strengthen Internal Security while Protecting Fundamental Rights, say MEPs', Press Release, Plenary Session, 22 May 2012, Reference No. 20120522 IPR45545.

Parliament and Council (1998), 'Decision No 2119/98/EC of the European Parliament and of the Council of 24 September 1998 setting up a network for the epidemiological surveillance and control of communicable diseases in the Community'.

Parliament and Council (2004), 'Regulation (EC) No 851/2004 of the European Parliament and of the Council Establishing a European Centre for Disease Prevention and Control', Brussels: 30 April 2004, Reference No. L $142 / 1$.

Phillips, L. (2000), The BSE Inquiry: The Report, The House of Commons, London.

Press Release (2005), 'Informal Meeting of EU Health Ministers', 20-21 October 2005: Pandemic Flu Preparedness, Press Release, Council of Ministers, Brussels. 
Quaglia, L. (2013), 'Is the European Union Governance Ready to Deal with the Next Financial Crisis?', in Hallerberg, M. (ed.), Governance Challenges and Innovations: Financial and Fiscal Policy, Oxford University Press, Oxford, Pp. 63-87.

Rhinard, M. (2009), 'European Cooperation on Future Crises: Toward a Public Good?', Review of Policy Research, Volume 26, Number 4, pp. 439-455.

Sabatier, P. and Jenkins-Smith, H. (eds) (1993), Policy Change and Learning: An Advocacy Coalition Approach, Westview Press, Boulder, CO.

Schinasi, G. J. and Teixeira, P. G. (2006), 'The Lender of Last Resort in the European Single Financial Market', IMF Working Paper 06/127.

Sundelius, B. (2005), 'Disruptions: Functional Security for the EU', Missiroli, A. (ed.), Disasters, Diseases, Disruptions: A New D-Drive for the European Union, Chaillot Paper No. 83, Institute for Security Studies, European Union, Paris, pp. 67-84.

Sundelius, B. and Grönvall, J. (2004), 'Strategic Dilemmas of Biosecurity in the European Union', Biosecurity and Bioterrorism, Volume 2, Number 1, pp. 17-23. Tercovich, G. (2014), 'Towards a Real Comprehensive Approach: The EEAS Crisis Response System', Journal of Contingencies and Crisis Management, Volume 22, Number 3, pp. 150-157.
Thwaites, N. (2006), 'Eurojust: Beacon in EU Judicial Co-operation', International Review of Penal Law, Volume 77, Number 1-2, pp. 293-298.

Van den Wyngaert, C. (2006), 'Eurojust and the European Public Prosecutor in the Corpus Juris Model: Water and Fire?', in Walker, N. (ed.), Europe's Area of Freedom, Justice and Security, Oxford University Press, Oxford, Pp. 201239.

Vincent, K. (2004), 'Mad Cows' and Eurocrats: Community Responses to the BSE Crisis', European Law Journal, Volume 10, Number 5, Pp. 499517.

Von Hippel, K. (2005), Europe Confronts Terrorism, Palgrave, New York.

Wendling, C. (2010), 'Explaining the Emergence of Different European Union Crisis and Emergency Management Structures', Journal of Contingencies and Crisis Management, Volume 18, Number 2, pp. 74-82.

Wolf, M. (2012), 'The Union outlived de Tocqueville', Financial Times, 18 April, p. 11.

Zimmermann, D. (2006), 'The European Union and Post-9/11 Counterterrorism: A Reappraisal', Studies in Conflict and Terrorism, Volume 29, Number 1, pp. 123-145. 